\title{
Active Family Control And Company Performance: The Role of Foreign Investment Moderation And Bank Debt
}

\author{
Perminas Pengeran \\ Fakultas Bisnis, Universitas Kristen Duta Wacana \\ Email:perminas@staff.ukdw.ac.id
}

\begin{abstract}
This study was to examine the moderating role of foreign ownership and Bank debt on the influence of active family control toward the family firm performance. Based on purposive sampling techniques, this study used 18 family firms listed in Indonesia Stock Exchange (IDX), during the period of 2006-2011. The results of this study showed several important findings. Firstly, foreign ownership positively moderated the effect of active family control on profitability. Secondly, likewise, bank debt negatively moderated the effect of active family control on profitability. Thirdly, foreign ownership negatively moderated the effect of active family control on dividends payment. Finally, bank debt positively moderated the influence of active family control on dividends payment. These results revealed that the foreign ownership and bank debt serves as moderator on the relationship between active family control and financial performance.
\end{abstract}

Keywords: Active Family Control, Foreign Ownership, Bank Debt, and Performance.

\section{INTRODUCTION}

Family controls have the potential to create conflicts between owners and owners, leading to the deprivation of wealth of minority owners by family owners (Yoshikawa and Rasheed, 2010; Jiang and Peng, 2011a). Family owners take over the wealth of minority shareholders, such as paying salaries and higher benefits for family executives and investing in other family-owned companies. The results prove that the first profitability decreases and then increases in line with the increase in family ownership (Maury, 2010) and active family control is closely related to high profitability (Shyu, 2011). In other words, when the family has greater control, the entrepreneur's potential effects and the company's bad performance grow larger. These emerging problems create conflicts between dominant owners such as the owner's family and other owners. Generally, this type of conflict is referred to as owner and owner conflict (Jiang and Peng, 2011b; Sauerwald, and Peng, 2013).

In this case, it is important to reduce this conflict of interest through the role of other external ownership, such as foreign ownership and ownership of the Bank. Although several studies have shown that foreign ownership and banks have an impact on the relationship between family control (Yoshikawa and Rasheed, 2010; Yen, et al., 2015), this role of ownership has not been explored in depth in the case of Indonesia. Therefore, the role of foreign ownership and the Bank on conflict of interest issues between owner and owner is the focus of this research.

The role of this external governance mechanism in an effort to reduce conflicts between dominant and minority owners is becoming increasingly important. The first way, through the role of foreign shareholders, ie foreign investors monitor the owner's family. 
This mechanism is effective for several reasons. First, a family-owned company is an issuer and has outside shareholders open the possibility that the company is subject to outside influences. Second, the presence of outside block holders can reduce this problem. They have some capacity to influence managerial decisions and actions, thereby reducing the possibility of a takeover by the family owned. Yoshikawa and Rasheed (2010) study results provide empirical support that foreign ownership as a majority shareholder can suppress the negative influence of family control on corporate financial performance. Likewise, the results of their studies show that foreign ownership interacts with family controls to reduce dividend payouts and increase profitability. Thus, it is likely that foreign ownership will minimize the negative effects of family control on dividend payouts and corporate profits. These results confirm that there is indeed an agency problem between owner and owner (principal-principal), (Estwick, 2015). These results encourage the importance of further research on whether the presence of external block holders can reduce the agency problem on the Indonesia Stock Exchange.

The role of the second external governance mechanism is the Bank's ownership or debt. Theoretically, the bank will prefer the company invested, although the company offers loans, can maintain the cash to reduce the risk of bankruptcy (Yoshikawa and Rasheed, 2010). Because the exposure to bank loan risk is greater than the ownership of shares in a borrowing company, the bank is expected to play more role as a creditor other than as a shareholder. According to Yoshikawa and Rasheed, (2010) that banks have an interest in high dividends and have the capacity to bring those results, and hence bank ownership in family-controlled firms may have a positive impact on dividends for some reason. First, recent research shows that bank ownership reduces agency problems, and dividend payouts are a reduction of agency problems by making discretionary cash flow less available to the owner's family. Second, dividends and/or interest when paid is income for the bank. Previous studies such as Morck et al. (2000), using a sample of Japanese firms, shows that banks have the ability to extract surplus from their clients. Finally, dividends have the same disciplinary property as the interest payments on the owner's family. Managers feel the pressure to increase the company's profitability so that the company can meet market expectations for dividend security. Failure to meet those expectations can be punished by the market as reflected in lower equity prices. Therefore, the bank expects the company to generate profits in order to pay dividends or interest.

Based on an explanation of prior agency issues and mitigation mechanisms of conflict of interest, this study aims to examine the role of moderation of foreign ownership and the Bank's debts on the influence of active family control on the financial performance of the company. The results of this study are expected to provide an explanation to the owners of funds in family firms in Indonesia, particularly about the role of foreign ownership and banks in reducing the negative impact of active family control on family firms financial performance.

\section{THEORITICAL REVIEW}

The Role of Moderation of Foreign Ownership on the Relationship of Active Family Control and Profitability of the Company. The impact of active control of the family on the performance of the company still remains the subject of a financial debate. According 
to Le Breton-Miller (2006) suggests that long tenors and business expertise encourage family business owners to invest in long-term time horizons. This condition is reinforced by the tendency of family owners to surrender their company to the next generation to succeed (Yoshikawa and Rasheed, 2010). Conversely, employed managers, if they are not closely monitored by family owners, may use short-term time horizons in their investment decision-making. Managers are only responsible for cash flows during their tenure. This can lead managers to the manipulation of short-term project accounting systems. A project that personally benefits managers at the expense of long-term investments, which have a higher NPV. Consequently, in the interest of managers, they tend to maximize performance-based buns.

Meanwhile, family ownership can have a detrimental effect on company performance. Yoshikawa and Rasheed (2010) describe the mechanisms of these adverse effects on the basis of three fundamental factors, namely the virtues of non-economic goals, the availability of other means to take over wealth, and the low competence of family human resources. First, the family company is not only ambitious to pursue profit but also non-economic goals. These noneconomic considerations will affect their behavior and performance (Vandemaele and Vancauteren, 2015). Second, family owners tend to have an incentive to take over the wealth of the company. This collection of wealth can be done through various ways such as excessive executive compensation for family managers. Third, family controls do not have sufficient competence required in the duties of corporate management. The scarcity of professional management and inadequate access to capital will lead to poor performance of family-controlled enterprises. In addition, the existence of nepotism (Jaskiewicz, et al., 2013), poor succession decisions based on incompetence rather than competence (Samei and Feyzbakhsh, 2015), and skepticism of financial markets (Ma, et al., 2016). Great family ownership will reduce the influence of other large shareholders on management, thus leading to a larger managerial camp (Estwick, 2015).

The negative effects of active control of the family also require other principal roles from outside the company. In this case, the role of foreign ownership becomes important. Therefore, for family owners to have economic incentives to increase the profitability of firms, the role of foreign ownership becomes important to monitor managers, thus undermining the negative influence of family control on corporate profitability. The main motivation of foreign institutional investors is to obtain financial benefits. Therefore, companies with large foreign ownership will pressure family managers to improve their financial performance. Therefore, it is expected that foreign ownership is positively related to the profitability of the company. Thus, the role of foreign investors is more likely to monitor managers, thus undermining the negative effects of family control over corporate profitability. Based on the above explanation, hypotheses can be formulated as follows:

$\mathbf{H}_{1}$ : Foreign ownership positively moderates the relationship between active family control and corporate profitability.

The Role of Moderation of Bank Ownership on the Relationship of Active Family Control and Profitability of the Company. Research results have also shown that bank ownership or bank debt can reduce agency problems in Japanese companies (Yoshikawa 
and Rasheed, 2010). In this case, according to Yoshikawa and Rasheed, (2010) the bank has an interest in the survival of the company because as a lender, bank funds are at risk. In addition, for its own sake, banks seek to maintain high equity prices because of their shareholding positions. As a provider of debt and capital owners, banks have a strong incentive to see that their client companies perform well so that profitable companies can pay their interest on the loan, pay back the principal amount when the loan matures, and also pay dividends when the bank as the owner (Yoshikawa and Rasheed, 2010). Banks will have a strong motivation for improving the company's performance. Because banks have insider access to corporate information from their client companies, it is difficult for corporate managers to seek personal gain. Therefore, banks can play the role of effective oversight. Such monitoring may weaken the negative relationship between family control and profitability. Thus on the explanation, the hypothesis can be arranged as follows:

$\mathbf{H}_{2}$ : Bank debt moderates positively the relationship between active family control and profitability.

The Role of Moderation of Foreign Ownership on the Relationship of Active Family Control and Dividend Payment. According to Wei, et al., (2011) that there are two types of agency problems that can exist in family firms. First, judging by the type of agency type I issue, family shareholders have greater incentives to monitor managers and encourage management to work more effectively. This agency problem is usually referred to as a 'convergence effect'. Family control can also sharpen the conflict of interest between the owner and manager, resulting in a " securities effect ". As a result of the lack of effective oversight, family shareholders, as insiders in the company, may use access to utilize the company's resources. This can increase agency costs and cause low dividend payouts. Incompetent family members who occupy key positions can affect the value of the company. In this case, family control has a negative influence on dividend policy.

Second, in terms of agency type II issues, family shareholders may misuse their position, to take the personal benefit at the expense of minority shareholders. This conflict occurs because of transfer pricing that benefits controlling shareholders, excessive executive compensation, dilutive share issues, and insider trading. This behavior by Johnson et al. (2000) is called "tunneling". The consequence of this behavior is the lower dividend payout because the company uses the company's resources for personal purposes. This behavior is consistent with indications of existing research results that family firms tend to pay lower cash dividends (Wei, et al., 2011; Vandemaele and Vancauteren, 2015).

Reduced negative effects of family control, requires another principal role from outside the company. Therefore, principal roles such as foreign ownership are needed so that family owners can have economic incentives to increase dividend payouts. In this case, the role of foreign ownership is more likely to monitor managers, thereby undermining the negative effects of active control of the family on the level of dividend payout companies. Thus, foreign share ownership may serve as a mechanism for improving corporate governance, especially in emerging markets. Chen, et al. (2009) provides evidence that foreign ownership has a positive relationship with the long-term performance of equity issuance due to increased independent and effective monitoring. Therefore, foreign ownership may contribute to mitigate the negative effects of family control, such as taking over the wealth of minority shareholders. 
Foreign investors tend to demand high dividend payouts. The empirical results of a positive relationship between foreign ownership and dividend payout are found in the case of Japanese manufacturing companies (Gedajlovic, et al., 2005). This result may be applicable in the case of investments in large companies in relatively established industries. Investors invest funds in companies in the Stock Exchange, with the aim of seeking dividend growth. Foreign investors are making a bigger bet to invest in a familycontrolled company. Therefore, foreign investors expect this higher risk to be rewarded with high returns as well. In addition, foreign institutional investors who have relatively large equity bets can also influence decision making in boardrooms. Ahmadjian and Robbins (2005) research indicate that Japanese executives are well aware of the proportion of their shares held by foreigners. Executives are increasingly making decisions by considering foreigners. Thus, the role of foreign ownership will suppress the positive relationship between active family control and payment of corporate dividends. Based on the previous explanation, hypotheses can be formulated as follows:

H3: Foreign ownership negatively moderates the relationship between active family control and dividend payout.

\section{Role of Debt Moderation of Banks on Active Family Control and Dividend Payment.}

Theoretically, it can be said that the bank will prefer the company invested, although the company offers loans, can maintain the cash to reduce the risk of bankruptcy (Yoshikawa and Rasheed, 2010). In many cases, because the exposure to bank loan risk is greater than the ownership of a share in a borrowing company, the bank is expected to play more role as a creditor other than as shareholder (Morck et al., 2000; Yoshikawa and Rasheed, 2010).

However, Yoshikawa and Rasheed, (2010) argue that banks have an interest in high dividends and have the capacity to bring that result. Therefore ownership of banks in family companies will have a positive impact on dividends for the following reasons. First, recent research shows that bank ownership reduces agency problems, and dividend payouts are a reduction of agency problems by making discretionary cash flow less available to the owner's family. Second, dividends and/or interest when paid is income for the bank. Previous studies such as Morck et al. (2000), using a sample of Japanese firms, shows that banks have the ability to extract surplus from their clients. Finally, dividends have the same disciplinary property as the interest payments on the owner's family. Managers feel the pressure to increase the company's profitability so that the company can meet market expectations for dividend security. Failure to meet those expectations can be punished by the market as reflected in lower equity prices. Therefore, the bank expects the company to generate profits in order to pay dividends or interest.

Banks give credit to their client companies and can also have substantial shares in companies. Role as the owner of the funds over the company, enabling the sharing of information between the bank and the client company. Since the company depends on its bank for future capital needs, it can be expected that banks will have an influence on the company's decisions, especially small and medium-sized family firms. Thus, the increase in bank debt, resulting in further weakening the relationship between increased family control and dividend payout. This can happen because of the emphasis on family controls 
that tend to take ownership of wealth on minority owners. Based on the theoretical explanation and the results of previous research, hypotheses can be proposed as follows: H4: Bank moderation debt positively the relationship between active family control and dividend payout.

Theoretical Model of Research. Figure 1 explains that foreign ownership positively moderates the influence of active family control over dividend payouts. The higher foreign ownership can play a role in suppressing the negative consequences of family control on the dividend payout rate. Foreign ownership and bank debt will suppress the negative effects of active family control on the level of profitability. Furthermore, foreign ownership and bank debt also moderate the influence of active family control over dividend payouts. Thus, the role of foreign ownership and bank debt is expected to be more likely to monitor managers, so that its role can weaken the negative impact of active family control on the company's financial performance.

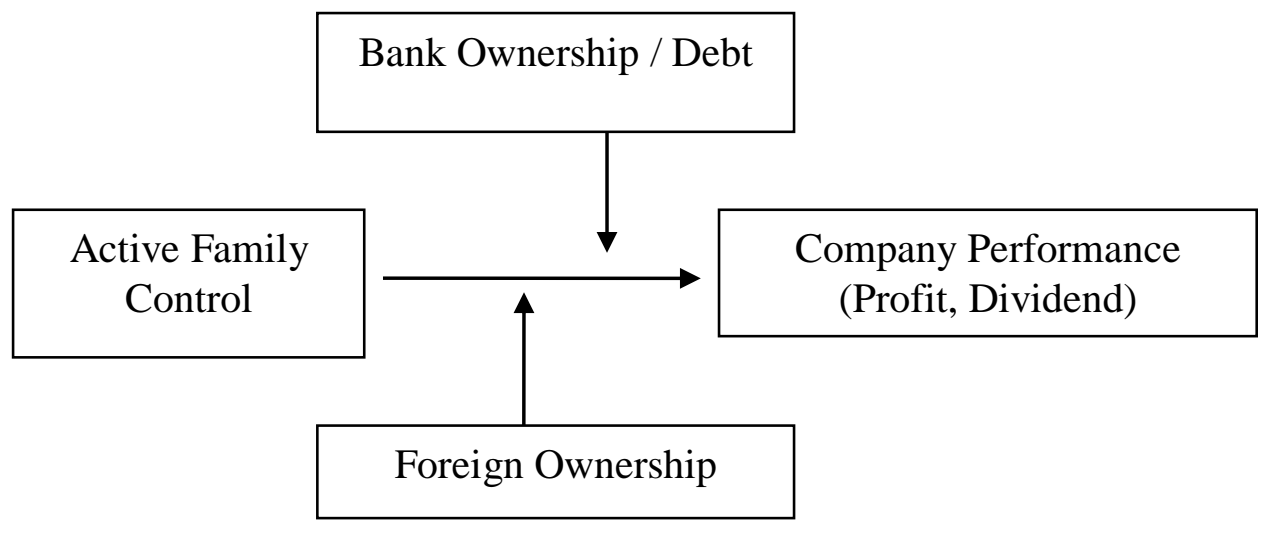

Figure 1. Theoretical Model

\section{METHOD}

Sample. This study uses samples from family firms listed on the Indonesia Stock Exchange. Sampling techniques from family companies based on the following criteria: 1) family firms listed on the Indonesia Stock Exchange during the years 2006-2011. 2) a family company whose shares are actively traded on the Indonesia Stock Exchange. 3) there is a board of directors that come from the family. 4) The board of directors of the family also has shares in the family. 5) has the same last name. 6) The family company has complete financial statements. 7) the family company has paid dividends during 20062011. 8) this family company has foreign ownership and Bank (bank debt) during the year 2006-2011. Based on these criteria, finally, the number of sample companies in this study are 16 family companies.

Definition of Operational variables. In this study, variables consist of independent variables, moderation, and dependent. Independent variable is family control, Moderator 
variable is foreign ownership and Bank Debt, while the dependent variable is family company performance measured by Return On Assets (ROA) and Dividend Pay Out Ratio (DPR).

Active family control. The control of the family company is the share of the ownership of the largest family director. In this case, companies own one (or several) members of the largest family shareholders on the board of directors. The family traits that are active in managerial family enterprises are having the same last name (Yoshikawa and Rasheed, 2010).

Foreign Ownership. Foreign ownership is the sum of the ownership of foreign investors in the family enterprise. Ownership Foreign investors in family firms include data from 2006-2011.

Bank Ownership. Bank ownership is measured by the proxy of the bank's debt-equity ratio by comparing the debt with the company's equity. Debt Ratio of Bank = Debt $/$ Equity Company Performance, ROA (Return On Total Assets). This ratio measures the company's ability to generate net income based on a certain level of an asset. This ratio is calculated as follows:

$\mathrm{ROA}=$ Net Income / Total Assets

Corporate Performance, Dividend Payout Ratio, Dividend Payout Ratio. This ratio looks at the share of earnings paid as dividends to investors. Other non-distributed parts will be reinvested in the company. The dividend payout ratio is calculated as follows.

Dividend Payout Ratio $=$ Dividend per share $/$ Earnings per share

Empirical Model. The Used Source Moderated Regression Analysis (MRA) model. Moderator variables both strengthen and weaken the relationship between independent variables and dependent variables. The moderator variable in this research is the role of foreign ownership and bank debt. The independent variable is the family control and the dependent variable is the financial performance. The Company's financial performance is measured by dividend payout ratio proxy and Return On Asset. So the moderator variable can be developed using two dimensions or characteristic. To determine the type of moderator variable, we must compare the three regression equations in each empirical model (Ghozali, 2009). Moderator variables are generally classified into three groups, i.e pure moderator, quasi-moderator, and homo glossier. Criteria for moderation variables are dependent and interacts with other independent variables, it is called the quasi moderator. If the moderator is not related to the criterion (dependent) and does not interact with other independent variables, it is called homoglogizer moderator. If the moderator variable is not related to the criterion (dependent) but interacts with other independent variables, it is called pure moderator.

Four empirical models can be formulated in the equation as follows:

Model 1.

Model 1a, $\mathrm{ROA}=\alpha+\beta 1 \mathrm{FC}+\mathrm{e}$ 
Model 1b, $\mathrm{ROA}=\alpha+\beta 1 \mathrm{FC}+\beta 2 \mathrm{FO}+\mathrm{e}$

Model 1c, $\mathrm{ROA}=\alpha+\beta 1 \mathrm{FC}+\beta 2 \mathrm{FO}+\beta 3 \mathrm{FC} * \mathrm{FO}+\mathrm{e}$

Where, ROA is Return on Asset, FC is Family Control, FO is Foreigner Ownership.

\section{Model 2.}

Model 2a, ROA $=\alpha+\beta 1 \mathrm{FC}+\mathrm{e}$

Model 2b, ROA $=\alpha+\beta 1 \mathrm{FC}+\beta 2 \mathrm{BD}+\mathrm{e}$

Model $2 \mathrm{c}, \mathrm{ROA}=\alpha+\beta 1 \mathrm{FC}+\beta 2 \mathrm{BD}+\beta 3 \mathrm{FC} * \mathrm{BD}+\mathrm{e}$

Where, ROA is Return on Asset, FC is Family Control, BD is Bank Debt.

Model 3.

Model 3a, DPR $=\alpha+\beta 1 \mathrm{FC}+\mathrm{e}$

Model 3b, DPR $=\alpha+\beta 1 \mathrm{FC}+\beta 2 \mathrm{FO}+\mathrm{e}$

Model 3c, DPR $=\alpha+\beta 1 \mathrm{FC}+\beta 2 \mathrm{FO}+\beta 3 \mathrm{FC} * \mathrm{FO}+\mathrm{e}$

Where, DPR is Deviden Payout Ratio, FC is Family Control, FO is Foreigner Ownership.

\section{Model 4.}

Model $4 \mathrm{a}, \mathrm{DPR}=\alpha+\beta 1 \mathrm{FC}+\mathrm{e}$

Model $4 \mathrm{~b}, \mathrm{DPR}=\alpha+\beta 1 \mathrm{FC}+\beta 2 \mathrm{BD}+\mathrm{e}$

Model $4 \mathrm{c}, \mathrm{DPR}=\alpha+\beta 1 \mathrm{FC}+\beta 2 \mathrm{BD}+\beta 3 \mathrm{FC} * \mathrm{BD}+\mathrm{e}$

Where, DPR is Deviden Payout Ratio, FC is Family Control, BD is Bank Debt.

This study also tested the classical assumption of an empirical model of this research, namely, residual normality test, heteroscedasticity test, autocorrelation test. The normality test aims to test whether in the regression model the residual variable is normally distributed. Autocorrelation test aims to test whether in a linear regression model there is a correlation between residual errors in period $t$ with the error in period $t-1$ (previous). The heteroscedasticity test aims to test whether a model has the same variance.

\section{RESULTS AND DISCUSSION}

Descriptive statistics. This study aims to examine the role of moderation of foreign ownership and bank debt on the influence of active family control on the financial performance of family firms. The financial performance of the family companies in this study used the ROA variable (return on asset) and DPR (dividend payout ratio). Data used in this research is secondary data sourced from Indonesia Capital Market Directory (ICMD) year 2006-2011.

Data collection is done by purposive sampling technique with the aim to get the sample in accordance with company criteria needed. The criteria used are family companies that have gone public and listed in the capital market in 2006-2011. Within those five consecutive years have data on family share ownership, foreign ownership, company profitability ratio, and dividend payout. The number of observations in this study was 90 observations. Description descriptive research data can be seen in table 1 .

Table 1. Descriptive Stastics 


\begin{tabular}{llrrrr}
\hline \multicolumn{1}{c}{ Variables } & N & Minimum & Maximum & \multicolumn{1}{c}{ Mean } & Std. Deviation \\
\hline Family Control (FC) & 90 & 5.02 & 23.92 & 7.679 & 4.262 \\
Foreigner Ownership (FO) & 90 & 3.52 & 60.21 & 21.745 & 18.389 \\
Bank Debt (BD) & 90 & .00 & 0.83 & 0.319 & 0.204 \\
$\quad$ FC x FO & 90 & 20.10 & 1440.22 & 211.726 & 324.493 \\
FC x BD & 90 & .00 & 78.94 & 18.158 & 20.502 \\
ROA & 90 & -4.33 & 49.57 & 5.766 & 6.483 \\
DPR & 90 & .00 & 47.73 & 7.256 & 10.813 \\
\hline
\end{tabular}

Source: data processed

Table 1 is a descriptive data on Family Control (KK), Foreign Ownership (KA), Bank Debt (UB), ROA, DPR. Table 1 explains that the mean value for family control is 7,679 . This figure reflects that the ownership of family shares is still small with a value of $8 \%$. Family control has a deviation of $4.262 \%$. The average value for foreign ownership of 21,745 or $22 \%$ indicates that the high foreign ownership in the family enterprise. Foreign ownership has a deviation of $18,389 \%$. Furthermore, the average value of bank debt, 0.319 .

The average ROA value in family firms is 5,766, indicating that the average family company in Indonesia has good asset management. ROA has a deviation of 6,483 . The average value of the House of Representatives is 7256 indicating that the average family in Indonesian companies pays dividends every year. The DPR has a deviation of 10,813.

Hypothesis testing. This study examines the influence of the role of foreign ownership and bank debt on the relationship between active family control and financial performance of family firms. The financial performance of the family companies in this study used ROA and DPR variables. In this study based on residual normality test results in equation model 1 and 2, the dependent variable is profitability, (ROA), indicating that the residual value is normally distributed. This is shown by the Kolmogorov-Smirnov $\mathrm{Z}$ test, with the p-value of 0.244 and 0.477 . It can be concluded that the residual value is normally distributed. test the hypothesis, the first step test the model assumption. Likewise, the residual normality test results in equation models 3 and 4 (the dependent variable is the profit distribution, DPR), indicating that the residual values are normally distributed. This is indicated by the results of the Kolmogorov-Smirnov $\mathrm{Z}$ test, a p-value of 0.689 and $0.471>\alpha=5 \%$. It can be concluded that the residual value is normally distributed.

Heterokedastisitas test in this study using Gleyser test by correlating the residual absolute value with each independent variable. Heteroskedasticity Test Results for model 1, providing parameters coefficient for independent variables FC (0.511) and FO (0.433) is not significant at 0.01 which means no heteroscedasticity. Likewise, the Heteroscedasticity Test Result for Model 2, giving the parameters coefficient for independent variables FC (0.526) and BER (0.645) is not significant at 0.01 meaning no heteroscedasticity. Heteroscedasticity test results for model 3, giving parameters coefficient for independent variables FC (0.211) and FO (0.065) is not significant at 0.01 which means no heteroscedasticity. Heteroskedasticity Test Results for model equation 4, giving parameters coefficient for independent variables FC (0.422) and BER (0.086) is not significant at 0.01 which means no heteroscedasticity. 
The results of the Breucsch-Godfrey test on models 1 and 2 show that each parameter coefficient for residual variables is $0.766>0.000$ and $0.589>0.000$. The results of this test indicate that there is no autocorrelation. The results of Breucsch-Godfrey test, on models 3 and 4 show that each parameter coefficient for residual variables is $0.432>$ 0.000 and $0.534>0.000$. The results of this test indicate that there is no autocorrelation.

The Role of Moderation in Foreign Ownership and Profitability. Based on table 2a., By comparing these three regression models, the results show that $\beta 2 \neq 0$ (significant) and $\beta 3 \neq 0$ (significant) it can be concluded that the foreign ownership variable (KA) is a quasi-moderator variable (pseudo-moderator).

Based on table $2 \mathrm{a}$, it shows that the coefficient of foreign ownership interaction and family control is positive and significant. Interaction variable coefficient (KK $* \mathrm{KA})$ is positive (0.016) and significant ( $\mathrm{p}$-value $=0.001<\alpha=5 \%$ ). This result also supports the second hypothesis (H1) which states that foreign ownership weakens the relationship of family control and corporate profitability. The results of this model test, also show family control negatively affect the profitability of family companies. This is in line with previous research results, that family control negatively affects the profitability of the company (Yoshikawa and Rasheed, 2010; Wisnu Aji, 2012). Similarly, foreign ownership affects the profitability of the company.

Tabel 2a. Result of Analysis of Role of Foreign Ownership Moderation

$$
\begin{gathered}
\text { Model 1a, ROA }=\alpha+\beta 1 \mathrm{FC}+\mathrm{e} \\
\text { Model 1b, ROA }=\alpha+\beta 1 \mathrm{FC}+\beta 2 \mathrm{FO}+\mathrm{e} \\
\text { Model 1c, ROA }=\alpha+\beta 1 \mathrm{FC}+\beta 2 \mathrm{FO}+\beta 3 \mathrm{FC} * \mathrm{FO}+\mathrm{e} \\
\text { Where, ROA is Return on Asset, FC is Family Control, FO is Foreigner Ownership. }
\end{gathered}
$$

\begin{tabular}{lrlrrrrr}
\hline \multirow{2}{*}{ Variables } & \multicolumn{2}{c}{ Model 1a } & \multicolumn{2}{c}{ Model 1b } & \multicolumn{2}{c}{ Model 1c } \\
\cline { 2 - 7 } & \multicolumn{1}{c}{$\beta$} & Sig & \multicolumn{1}{c}{$\beta$} & \multicolumn{1}{c}{ Sig } & \multicolumn{1}{c}{$\beta$} & \multicolumn{1}{c}{ Sig } \\
\hline Constant & 1.710 & 0.000 & 1.778 & .000 & 3.853 & 0.000 \\
Family Control (FC) & -0.032 & 0.167 & .006 & .835 & -0.318 & 0.002 \\
Foreigner Ownership (FO) & & & -.016 & .016 & -0.054 & 0.000 \\
FC*FO & & & & & 0.016 & 0.001 \\
\hline
\end{tabular}

Information: Dependent variable is ROA

Source: data processed

The Role of Moderation of Bank Ownership (Debt) and Profitability. Likewise, based on table $2 b$, these three regression models obtained the result that $\beta 2 \neq 0$ (significant) and $\beta 3 \neq 0$ (significant) it can be concluded also that the variable of bank ownership or bank debt (BD) is a quasi-moderator variable (pseudo-moderator). Based on table $2 b$, it shows that the coefficient of foreign ownership interaction and family control is negative and significant. Interaction variable coefficient $(\mathrm{FC} * \mathrm{BD})$ is negative $(-1.028)$ and significant ( $\mathrm{p}$-value $=0,042<\alpha=5 \%$ ). This result is inconsistent with the prediction of the second hypothesis $\left(\mathrm{H}_{2}\right)$ which states that bank debt weakens the relationship between family control and profitability. 
Tabel 2b. Role Analysis Results of Debt Moderation Bank

\begin{tabular}{|c|c|c|c|c|c|c|}
\hline $\begin{array}{r}\text { Model } \\
\text { Where, ROA is }\end{array}$ & $\begin{array}{l}\mathrm{ROA}= \\
=\alpha+ \\
1 \mathrm{FC} \\
\mathrm{FC} \mathrm{i}\end{array}$ & $\begin{array}{l}+\beta 1 \mathrm{~F} \\
\mathrm{FC}+ \\
2 \text { BD } \\
\text { amily }\end{array}$ & $\begin{array}{l}\mathrm{B} \\
\mathrm{BD}+ \\
3 \mathrm{FC} * \\
\text { ontrol, }\end{array}$ & $\begin{array}{l}D+e \\
D \text { is } \mathrm{E}\end{array}$ & 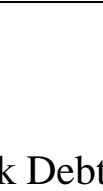 & \\
\hline Variables & Mod & & Mode & & Mod & \\
\hline & $\beta$ & Sig & $\beta$ & Sig & $\beta$ & Sig \\
\hline Constant & 2.145 & .000 & 2.753 & .000 & 2.555 & .000 \\
\hline Family Control (FC) & -.389 & .145 & -.350 & .181 & .627 & .207 \\
\hline Bank Debt (BD) & & & -.216 & .036 & .898 & .072 \\
\hline $\mathrm{FC} * \mathrm{BD}$ & & & & & -1.028 & .023 \\
\hline
\end{tabular}

Information: Dependent variable is ROA

Source: data processed

The Role of Moderation of Foreign Ownership and House of Representatives. Next, according to table $3 \mathrm{a}$, from the three regression models in table $3 \mathrm{a}$, the empirical results show that $\beta 2 \neq$ (significant) and $\beta 3 \neq 0$ (significant) it can be concluded that the Foreign Ownership (FO) variable is the quasi-moderator variable (pseudo-moderator). Based on the test results as in table $3 \mathrm{a}$, it shows that the coefficient of foreign ownership interaction and family control is negative and significant. In this case, the interaction variable coefficient $(\mathrm{FC} * \mathrm{FO})$ is negative $(-1.503)$ and significant ( $\mathrm{p}$-value $=0.003<\alpha=5 \%$ ). This result supports the third hypothesis $(\mathrm{H} 3)$ which states that foreign ownership negatively moderates the influence of family control and dividend payout.

Tabel 3a. Result of Analysis of Role of Foreign Ownership Moderation Model 3a, DPR $=\alpha+\beta 1 \mathrm{FC}+\mathrm{e}$ Model 3b, DPR $=\alpha+\beta 1 \mathrm{FC}+\beta 2 \mathrm{FO}+\mathrm{e}$

Model $3 \mathrm{c}, \mathrm{DPR}=\alpha+\beta 1 \mathrm{FC}+\beta 2 \mathrm{FO}+\beta 3 \mathrm{FC} * \mathrm{FO}+\mathrm{e}$

Where, DPR is Deviden Payout Ratio, FC is Family Control, FO is Foreigner Ownership.

\begin{tabular}{lcccccc}
\hline \multirow{2}{*}{ Variables } & \multicolumn{2}{c}{ Model 3a } & \multicolumn{2}{c}{ Model 3b } & \multicolumn{2}{c}{ Model 3c } \\
\cline { 2 - 7 } & $\mathrm{B}$ & $\mathrm{Sig}$ & $\mathrm{B}$ & $\mathrm{Sig}$ & $\mathrm{B}$ & $\mathrm{Sig}$ \\
\hline Constan & 2.021 & 0.000 & 2.109 & 0.000 & 6.922 & 0.000 \\
Family Control (FC) & -0.057 & 0.075 & -0.008 & 0.825 & 0.103 & 0.045 \\
Foreigner Ownership (FO) & & & -0.021 & 0.023 & 0.042 & 0.062 \\
FC*FO & & & & & -1.503 & 0.003 \\
\hline
\end{tabular}

Information: Dependent variable is DPR

Source: data processed

The Role of Moderation of Ownership (Debt) of Banks and House of Representatives. Finally, based on table 3 b, by comparing these three regression models, the results show that $\beta 2=$ (not significant) and $\beta 3 \neq 0$ (significant) it can be concluded that 
the variable of Ownership or Debt Bank is the pure moderator variable (pure moderator). The following $3 \mathrm{~b}$ thread describes three models of testing the role of bank debt moderation.

Tabel 3b. Hasil Analisis Peran Moderasi Utang Bank

$$
\text { Model 4a, DPR }=\alpha+\beta 1 \mathrm{FC}+\mathrm{e}
$$

Model $4 \mathrm{~b}, \mathrm{DPR}=\alpha+\beta 1 \mathrm{FC}+\beta 2 \mathrm{BD}+\mathrm{e}$

Model $4 \mathrm{c}, \mathrm{DPR}=\alpha+\beta 1 \mathrm{FC}+\beta 2 \mathrm{BD}+\beta 3 \mathrm{FC} * \mathrm{BD}+\mathrm{e}$

Where, DPR is Deviden Payout Ratio, FC is Family Control, BD is Bank Debt.

\begin{tabular}{lcccccc}
\hline \multirow{2}{*}{ Variables } & \multicolumn{2}{c}{ Model 4a } & \multicolumn{2}{c}{ Model 4b } & \multicolumn{2}{c}{ Model 4c } \\
\cline { 2 - 7 } & $\mathrm{B}$ & $\mathrm{Sig}$ & $\mathrm{B}$ & $\mathrm{Sig}$ & $\mathrm{B}$ & Sig \\
\hline Constan & 3.470 & .000 & 3.110 & .001 & 4.192 & .000 \\
Family Control (FC) & -.965 & .008 & -.972 & .008 & -3.258 & .000 \\
Bank Debt (BD) & & & .114 & .526 & -2.646 & .000 \\
FC*BD & & & & & 2.389 & .000 \\
\hline
\end{tabular}

Information: Dependent variable is DPR

Source: data processed

Based on the test results as in table $3 \mathrm{~b}$, it shows that the coefficient of ownership interaction or bank debt and family control is positive and significant. In this case, the interaction variable coefficient $(\mathrm{KK} * \mathrm{UB})$ is positive $(2,389)$ and significant (p-value $=$ $0,000<\alpha=5 \%$ ). This result supports the first hypothesis (H4) which states that bank ownership or debt positively moderates the influence of family control and dividend payout.

The Role of Moderation of Foreign Ownership on the Relationship of Active Family Control and Profitability of the Company. The results show that foreign ownership positively moderates the influence of family control and profitability. This result supports the first hypothesis $\left(\mathrm{H}_{1}\right)$. These results indicate the role of foreign ownership in reducing the negative effects of family control on profitability. In accordance with existing data, the amount of foreign ownership, on average $25 \%$, in this case, foreign investors have the capacity to influence managerial decisions and actions. Foreign ownership may reduce the possibility of a takeover by the family owned. The higher foreign ownership in the family company will suppress the negative effects of the owners' family control on the profitability of the company.

The results of this study are consistent with the findings of Yoshikawa and Rasheed (2010). Yoshikawa and Rasheed, (2010) prove that foreign ownership positively moderates the influence of family control and profitability. Negative effects of family control on profitability can be suppressed by the presence of a substantial foreign ownership role. The adverse effects of family control can occur because of three fundamental factors, namely the virtues of non-economic goals, the availability of other means to take possession of wealth, and disability. First, the family company is not only ambitious to pursue profit, but also on non-economic considerations. This will affect their behavior and results. Second, the family owner may have an incentive to take over the 
wealth of the company by setting excessive executive compensation for the family manager. Third, the company controlled by the family may have lower performance because of the low quality of human resources and inadequate access to capital.

The Role of Bank Loan Moderation on Active Family Control Relations and Profitability of the Company. The results show that bank ownership or debt negatively moderates the influence of active family control on profitability. This result is inconsistent with the prediction of the second hypothesis $\left(\mathrm{H}_{2}\right)$. Thus, the results of this study do not support the research of Yoshikawa and Rasheed, (2010). These results indicate that bank debt will strengthen the negative effects of active family control on profitability. This can happen because of several possibilities. The bank has an interest in the survival of the company as a lender, with risky bank funds. As a provider of debt as well as owners of capital, banks have a strong incentive to see that their client companies are performing well so that profitable companies can pay their interest on the loan, pay back the principal amount when the loan is due (Yoshikawa and Rasheed, 2010). Although the Bank will have strong motivation in improving the performance of the company, the bank seems less able to suppress the negative effects of family control on the profitability of the company. In this case, the bank should be able to play the role of effective oversight. Such monitoring should weaken the negative relationship between family control and profitability.

The Role of Moderation of Foreign Ownership on Active Family Control and Dividend Payout. The results show that foreign ownership negatively moderates the influence of family control on dividend payouts. This result is consistent with the prediction of the third hypothesis $(\mathrm{H} 3)$. These results indicate that foreign ownership strengthens the negative relationship between active family control and dividend payout ratio. This result can occur because of the lack of effective role of foreign equity ownership in family companies. Foreign ownership is less able to encourage active family owners to improve the distribution of earnings for cash dividend payments. In this case, the owner of the foreign fund wants some profit to be shared with them.

The results also show that active family control negatively affects dividend payouts. This can be explained in accordance with Wei's income, et al., (2011). They claimed that the family shareholders could abuse their position, to take personal benefit at the expense of minority shareholders. This conflict occurs because of transfer pricing that benefits controlling shareholders, excessive executive compensation, dilutive share issues, and insider trading. This behavior by Xu'nan (2011) is called "tunneling". This behavior seriously harms the interests of minority shareholders. The consequence of this behavior is the lower dividend payout, because the company uses the company's resources for other purposes. This behavior is consistent with the results of Wei et al's study. (2011) indicates that family firms tend to pay lower cash dividends.

The Role of Bank Loan Moderation on Active Family Control and Dividend Payout. The results show that foreign ownership positively moderates the influence of family control on dividend payouts. This result supports the fourth hypothesis (H4). These results reveal that foreign ownership will weaken the negative impact of family control on the dividend payout ratio. This result can be due to several possibilities. First, the bank has an 
interest in repayment of loan interest and loan principal. In this case, the bank has the capacity to bring the result, and therefore the bank debt in the family company it controls has the effect of suppressing the negative effects of family control on dividend policy. Bank debt can reduce agency problems and dividend payouts also reduce agency problems by making less cash flow available to the owner's family.

Second, interest when paid, is income for the bank. Previous studies such as Morck et al. (2000), using a sample of Japanese firms, shows that banks have the ability to extract surplus from their clients. Third, dividends have the same disciplinary property as the interest payments on the owner's family. Managers feel the pressure to increase the company's profitability so that the company can meet market expectations for dividend security. Failure to meet these expectations may be responded negatively by the market, which is reflected in the decline in equity prices. Therefore, the bank expects the company to generate profits in order to pay interest and dividends.

\section{CONCLUSION AND LIMITATIONS}

Conclusion. Based on the results of the previous analysis and discussion, it can be concluded several important things. First, foreign ownership moderates positively the influence of active family control on profitability. These results reveal that if the family company has high foreign ownership then foreign investors influence the family to increase the profitability level of the company. Second, the results show that bank debt moderates negatively the influence of active family control and profitability. These results are interesting because bank debt strengthens the negative impact of active family control on corporate profitability. Third, foreign ownership negatively moderates the influence of active family control over dividend payments. These results indicate that foreign ownership affects active family controls to increase the dividend payout ratio. Fourth, the results show that bank debt moderates positively over the influence of active family control on dividend payouts. These results reveal that the Bank's debt will weaken the negative impact of active family control on dividend payouts.

Limitations and Research Suggestions Ahead. First, in this study using the sample size of family companies that are still relatively small. The study was limited to family companies that went public in BEI 2006-2011. For that, future research can consider the period of increasing the period of research so that it can increase the sample size. Second, this research does not consider control variables, that is other variables that can affect the company's financial performance. Therefore, future research may consider control variables such as firm size, firm age, firm equity ratio, firm growth. Third, in this study, active family control is procured by the largest shareholding of family directors, while there are still some other proxies, such as the ratio of the number of family directors in family firms. Likewise, the variable of bank ownership is proxied by bank debt. Future research may consider bank ownership as a moderating variable. Fourth, in this study has not considered the role of moderation in corporate growth. Future research can test whether firms retain earnings to finance investment opportunities at a time of high growth.

\section{REFERENCES}


Ahmadjian, C. L. and Robbins, G. E. (2005). "A clash of capitalisms: foreign shareholders and corporate restructuring in 1990s Japan". American Sociological Review, 70, 451-71.

Chen, Y.R., Chiou, J.R., Chou, T.K. and Syue, M.S. (2009). "Corporate governance and long-run performance of equity issues: The role of foreign ownership in Taiwan". Asia Pacific Management Review, 14, 27-46.

Estwick, S. (2015). "The Impact of Principal-principal Conflict on Financial Flexibility in Transition Economies: A Study of Caribbean Firms". Journal of Eastern Carribean Studies, 40(2), 99-123

Gedajlovic, E., Yoshikawa, T. and Hashimoto, M. (2005). Ownership structure, investment behavior and firm performance in Japanese manufacturing industries. Organization Studies, 26, 7-35.

Ghozali, I. (2009). Analisis Multivariate Lanjutan dengan Program SPSS. Cetakan 4. Badan Penerbit Universitas Diponegoro. Semarang.

Jaskiewicz, P., Uhlenbruck, K., Balkin, D.B., and Reay, T. (2013). "Is Nepotism Good or Bad? Types of Nepotism and Implications for Knowledge Management". Family Business Review, 26(2) 121-139.

Jiang, Y., and Peng, M. W. (2011a). "Are Family Ownership And Control In Large Firms Good, Bad, Or Irrelevant?”. Asia Pacific Journal of Management, 28(1), 15-39.

Jiang, Y., and Peng, M. W. (2011b). "Principal-principal Conflicts During Crisis". Asia Pacific Journal of Management, 28(4): 683-695.

Johnson, S., La Porta, R., Lopez-de Silanes, F., Shleifer, A., (2000). Tunneling. American Economic Review, 90 (1), 20-27.

Le Breton-Miller, I. and Miller, D. (2006). Why do some family businesses out-compete? Governance,long-term orientations, and sustainable capability. Entrepreneurship: Theory and Practice, 30, 731-46.

Ma, L., Ma, S. and Tian, G. (2016). Family control, accounting misstatements, and market reactions to restatements: Evidence from China. Emerging Markets Review, 28: $1-27$

Maury, B. (2010). "Family ownership and firm performance: Empirical evidence Kam Western European corporations". Journal of Corporate Finance, 12, 321-341.

Morck, R., Nakamura, M. and Shivdasani, A. (2000). "Banks, ownership structure, and firm value in Japan". Journal of Business, 73, 539-67.

Samei, H. and Feyzbakhsh, A. (2015). "Predecessors competency framework for nurturing successors in family firms". International Journal of Entrepreneurial Behavior \& Research, 21(5), 731 - 752

Sauerwald, S. and Peng, M.W. (2013). "Informal institutions, shareholder coalitions, and principal-principal conflicts". Asia Pacific Journal of Management, 30 (3): 853-870.

Shyu, J. (2011). "Family ownership and firm performance: evidence from Taiwanese firms". International Journal of Managerial Finance, 7 (4), 397- 411

Yen, J. Lin, C., Chen, Y. and Huang, Y. (2015). "Founding Family Firms and Bank Loan Contracts". Journal of Financial Services Research, 48 (1), 53-82

Yoshikawa, T. and Rasheed, A. (2010). "Family Control and Ownership Monitoring in Family-controlled Firms in Japan". Journal of Management Studies 47(2), 274-295 
Vandemaele, S. and Vancauteren, M. (2015). "Nonfinancial Goals, Governance, and Dividend Payout in Private Family Firms". Journal of Small Business Management, 53 (1), $166-182$.

Wei, Z., Wu, S., Li, Ch., and Chen, W. (2011). "Family control, institutional environment and cas h dividend policy: Evidence KAm China". China Journal of Accounting Research, 4, 29-46.

Wisnu Aji, G. (2012) "Pengaruh Kontrol Keluarga Terhadap Kinerja Perusahaan Keluarga Dengan Kepemilikan Asing Sebagai Pemoderasi”. Skripsi. Fakultas Bisnis, UKDW.

Xu'nan, F. (2011). "Dividends and tunneling: evidence from family firms in China'. China Finance Review International, 1 (2),152-167. 